\title{
PERAN BADAN AMIL ZAKAT (BAZ) DALAM MENINGKATKAN JUMLAH MUZAKKI (Studi Kasus Di BAZ Kabupaten Nganjuk)
}

\author{
Oleh \\ Mas'ut \\ Institut Agama Islam Pangeran Diponegoro Nganjuk \\ masud@iaipd-nganjuk.ac.id
}

\begin{abstract}
The management of zakat is an urgent matter, the zakat institution is said to be successful or backward lies in the mechanism for managing zakat funds. Regarding the implementation of zakat in the community, besides still needing guidance in terms of shari'ah and the development of zakat, there is also an attitude of lack of trust in the implementation of zakat because of the mistakes made by the zakat institution. The management of zakat in the community still requires proper and steady guidance and methods. So that people do not share their own charity with those in need. This lack of trust can be reduced, if a good organization is created, especially the administrative system, strict and perfect supervision. To carry out zakat management, the Government established the National Zakat Agency (BAZNAS). National Zakat Agency (BAZNAS) is an institution formed by the government based on Law No. 38 of 1999 and Law No. 23 of 2011. The zakat institution, the scope of its operations can be at the regional or national level. The growth of zakat institutions is a reflection of the emergence of awareness of the need for institutions that are able to manage community charity. In addition, this is the result of the zakat institution's work in developing community welfare.
\end{abstract}

Keywords: Amil Zakat Agency, Number of Muzaki, Management of Zakat

\begin{abstract}
Abstrak
Pengelolaan zakat menjadi sebuah persoalan yang urgen, institusi zakat dikatakan berhasil atau mundur terletak pada mekanisme dalam mengelola dana zakat. Tentang pelaksanaan zakat di masyarakat, disamping masih memerlukan bimbingan dari segi syari'ah maupun
\end{abstract}


perkembangan zakat, ada juga sikap kurang percaya terhadap penyelenggaraan zakat karena kesalahan-kesalahan yang dibuat oleh lembaga zakat tersebut. Pengelolaan zakat di masyarakat masih memerlukan tuntunan serta metode yang tepat dan mantap. Agar masyarakat tidak membagikan sendiri zakatnya kepada orang-orang yang membutuhkan. Sikap kurang percaya tersebut akan dapat dikurangi, jika diciptakan organisasi yang baik terutama sistem administrasinya, pengawasan yang ketat dan sempurna. Untuk melaksanakan pengelolaan zakat, Pemerintah membentuk Badan Amil Zakat Nasional ( BAZNAS). Badan Amil Zakat Nasional (BAZNAS) adalah sebuah lembaga yang dibentuk oleh pemerintah berdasarkan UU No. 38 Tahun 1999 dan UU No. 23 Tahun 2011. Lembaga zakat tersebut, lingkup operasinya bisa ditingkat regional ataupun nasional. Tumbuhnya lembaga zakat merupakan cermin timbulnya kesadaran akan perlunya lembaga yang mampu mengelola zakat-zakat masyarakat. Selain itu, hal ini merupakan hasil yang telah dilakukan lembaga zakat tersebut dalam membangun kesejahteraan masyarakat.

Kata Kunci: Badan Amil Zakat, Jumlah Muzaki, Pengelolaan Zakat

\section{Pendahuluan}

Zakat merupakan salah satu rukun Islam. Oleh sebab itu, hukum zakat adalah wajib (fardhu) atas setiap muslim yang telah memenuhi syarat-syarat tertentu. Zakat merupakan bentuk ibadah. sama halnya dengan shalat, haji, dan puasa yang telah diatur secara rinci berdasarkan Al-Qur'an dan As-Sunnah. Zakat juga merupakan kegiatan sosial kemasyarakatan dan kemanusiaan yang dapat berkembang sesuai dengan perkembangan umat manusia dimana pun.

Secara bahasa zakat berarti an-numu wa az-ziyadah (tumbuh dan bertambah). Kadang dipakaikan dengan makna ath-thaharah (suci). dan al-barkah (berkah).Zakat dalam pengertian suci adalah membersihkan diri, jiwa, dan harta. Seseorang yang mengeluarkan zakat berarti dia telah membersihkan diri dan jiwanya dari penyakit kikir , serta membersihkan hartanya dari hak orang lain, serta membersihkan hartanya dari hak orang lain yang ada dalam harta tersebut. 
Pengelolaan zakat menjadi sebuah persoalan yang urgen, institusi zakat dikatakan berhasil atau mundur terletak pada mekanisme dalam mengelola dana zakat. Tentang pelaksanaan zakat di masyarakat, disamping masih memerlukan bimbingan dari segi syari'ah maupun perkembangan zakat, ada juga sikap kurang percaya terhadap penyelenggaraan zakat karena kesalahan-kesalahan yang dibuat oleh lembaga zakat tersebut. Pengelolaan zakat di masyarakat masih memerlukan tuntunan serta metode yang tepat dan mantap. Agar masyarakat tidak membagikan sendiri zakatnya kepada orangorang yang membutuhkan. Sikap kurang percaya tersebut akan dapat dikurangi, jika diciptakan organisasi yang baik terutama sistem administrasinya, pengawasan yang ketat dan sempurna.

Para amil zakat disyaratkan memenuhi beberapa kriteria, di antaranya dapat dipercaya, adil, mempunyai perhitungan yang benar, berakhlak baik, mempunyai pemahaman yang jelas tentang zakat, tidak dzolim dan tidak menerima hadiah. Untuk melaksanakan pengelolaan zakat, Pemerintah membentuk Badan Amil Zakat Nasional ( BAZNAS). Badan Amil Zakat Nasional (BAZNAS) adalah sebuah lembaga yang dibentuk oleh pemerintah berdasarkan UU No. 38 Tahun 1999 dan UU No. 23 Tahun 2011. Lembaga zakat tersebut, lingkup operasinya bisa ditingkat regional ataupun nasional. Tumbuhnya lembaga zakat merupakan cermin timbulnya kesadaran akan perlunya lembaga yang mampu mengelola zakat-zakat masyarakat. Selain itu, hal ini merupakan hasil yang telah dilakukan lembaga zakat tersebut dalam membangun kesejahteraan masyarakat.

Zakat merupakan sebuah sistem yang banyak mengandung pesan-pesan keadilan sosial, mengatasi kesenjangan, mengangkat harkat dan martabat umat Islam serta mengatasi kegelisahan masyarakat akibat persoalan ekonomi. Oleh karena itu, sosialisasi dalam menumbuhkan kesadaran berzakat di kalangan muzakki harus terus digencarkan oleh lembaga amil zakat. Untuk mewujudkan kesejahteraan masyarakat dan mempercepat pemberantasan kemiskinan yang ada di masyarakat, sangat dibutuhkan peran dan fungsi lembaga amil zakat, sehingga lembaga ini benar-benar dipercayai oleh muzakki. 
Melihat latar belakang tersebut, penulis tertarik untuk mengetahui lebih jauh tentang lembaga amil zakat kaitannya dengan peningkatan jumlah muzakki dan penulis mengambil Badan Amil Zakat Kabupaten Nganjuk sebagai obyek penelitian. Untuk itu dalam skripsi ini penulis akan mengambil judul "Peran Badan Amil Zakat (BAZ) Dalam Meningkatkan Jumlah Muzakki “

\section{Metode Penelitian}

Penelitian ini menggunakan system penelitian lapangan, yaitu obyek utamanya adalah mengenai pengelolaan zakat di Badan Amil Zakat Kabupaten Nganjuk untuk meningkatkan kesadaran masyarakat muzakki, pandangan Hukum Islam terhadap kebijakan Badan Amil Zakat Kabupaten Nganjuk dalam meningkatkan kesadaran masyarakat muzakki dan kendala apa saja yang selama ini dihadapi. Dalam penelitian ini pendekatan yang di lakukan adalah melalui pendekatan kualitatif. Metode yang digunakan dalam penelitian ini adalah metode deskriptif.

Guna memecahkan suatu permasalahan tersebut, dilakukan suatu penelitian guna mendapat informasi yang akurat sehingga masalah tersebut dapat diselesaikan dengan baik dan bahkan dapat memperkaya wawasan baru yang dapat digunakan bagi pengembangan llmu lebih lanjut. Masalah adalah setiap kesulitan yang menggerakan manusia untuk mencari solusinya karena apabila dibiarkan dapat lebih membahayakan atau mengganggu tatanan. Masalah dalam penelitian adalah bidang garapan keilmuan yang harus dipikirkan secara kritis dan selektif dan pemecahannya harus didasarkan pada data/fakta yang diolah secara valid dan reliabel60.

Dalam penelitian ini peneliti langsung terjun kelapangan untuk mencari data yang di inginkan. Peneliti bertindak sebagai pengamat. Sebagai pengamat, peneliti berperan serta dalam kehidupan sehari-hari subyeknya pada setiap situasi yang diinginkannya untuk dapat dipahaminya.

${ }^{60}$ Ibid., 25. 
Peran sebagai instrumen sekaligus pengumpul data itu penulis realisasikan dengan berinteraksi langsung dengan objek. Untuk menjadi instrumen penelitian yang baik peneliti kualitatif dituntut untuk memiliki wawasan yang luas baik wawasan teoritis maupun wawasan yang terkait dengan kontak sosial yang diteliti.61 Hal tersebut dapat berupa nilai, budaya, keyakinan, hukum, adat istiadat yang terjadi dan berkembang pada konteks sosial tersebut. Bila peneliti tidak memiliki wawasan yang luas maka peneliti akan sulit membuka pertanyaan kepada sumber data sulit memahami apa yang terjadi dan tidak akan dapat melakukan analisis secara induktif terhadap data yang diperoleh. Sebagai contoh seorang peneliti bidang manajemen akan merasa sulit untuk mendapatkan data tentang kesehatan karena untuk bertanya pada bidang kesehatan saja akan mengalami suatu kesulitan.

Kehadiran peneliti dalam penelitian ini adalah untuk menemukan dan mengeksplorasi dengan menggunakan metode observasi yaitu peneliti hanya mengamati objek penelitian untuk mengetahui bagaimana upaya yang dilakukan Badan Amil Zakat Kabupaten Nganjuk dalam meningkatkan jumlah muzakki. Sedangkan jenis data yang digunakan dalam penelitian ini adalah penelitian kualitatif. Dalam penelitian kualitatif, data yang dikumpulkan berupa data desktiptif, yakni yang utama adalah semua data dan informasi yang diperoleh dari para informan baik yang berupa kata-kata dan tindakan yang diamati atau yang diwawancarai, selain itu dapat berupa dokumen dan lainnya.

\section{Hasil Dan Pembahasan}

\section{Kajian Badan Amil Zakat}

Badan Amil Zakat adalah organisasi pengelola zakat yang dibentuk oleh pemerintah terdiri dari unsur masyarakat dan pemerintah dengan tugas mengumpulkan, mendayagunakan dan mendistribusikan zakat sesuai dengan ketentuan agama.Amil Zakat

\section{${ }^{61}$ Sugiyono. Metode Penelitian Kuantitatif Kualitatif Dan}

$R \& D$. Bandung: Alfabeta, 2014, 213. 
adalah mereka yang diangkat oleh phak yang berwenang yang di berikan tugas untuk melaksanakan berbagai kegiatan yang berkaitan dengan urusan zakat. ${ }^{62}$ Secara garis besar tugas amil meliputi tugas pengumpulan zakat dari muzakki dan tugas pendistribusian zakat kepada mustahiq.

Termasuk dalam lingkup tugas pengumpulan zakat antara lain melakukan sensus terhadap orang yang wajib zakat (muzakki), macam harta yang mereka miliki, dan besar harta yang wajib dizakati Kemudian menagihnya dari para wajib zakat, menyimpan dan menjaganya untuk kemudian diserahkan kepada pengurus pembagi zakat. Sedangkan tugas pembagi zakat antara lain memilih cara yang paling baik untuk mengetahui para penerima zakat (mustahik) kemudian melaksanakan klarifikasi terhadap mereka dan menyatakan hak-hak mereka. Juga menghitung jumlah kebutuhan mereka dan jumlah biaya yang cukup untuk mereka.

Organisasi Pengelola Zakat di Indonesia terdiri atas Badan Amil Zakat (BAZ) dan Lembaga Amil Zakat (LAZ). BAZ dibentuk oleh pemerintah di bawah naungan Kementerian Agama, dan tersebar hampir di setiap tingkatan baik tingkat nasional, provinsi, kabupaten/kota,hingga kecamatan. Perbedaan BAZ dengan Lembaga Amil Zakat (LAZ) adalah, BAZ adalah lembaga yang dibentuk pemerintah, sementara LAZ adalah lembaga yang dibentuk masyarakat yang bertugas untuk mengumpulkan, mendistribusikan, dan mendayagunakan zakat (UU No.23 Tahun 2011).

Perhatian pemerintah tehadap Organisasi Pengelola Zakat cukup besar. Setelah menerbitkan UU No. 38 Tahun 1999 tentang pengelolaan zakat, pada tahun 2011, pemerintah kembali menerbitkan UU No.23 tahun 2011 sebagai pengganti UU No. 38 Tahun 1999. Pembentukan Undang-undang ini diharapkan mampu memperbaiki sistem pengelolaan zakat di Indonesia, sehingga optimalisasi zakat dapat tercapai. Selain itu, para ahli profesi seperti Ikatan Akuntan Indonesia, juga turut memberikan sumbangsih guna mencapai

${ }^{62}$ Nurul Huda Mohamad Heykal.Lembaga Keuangan

Islam,Kencana Prenada Media GroupJakarta:,2010,301 
pengelolaan zakat yang baik dengan menerbitkan PSAK 109 tentang Akuntansi Zakat, dengan harapan terwujudnya Organisasi Pengelola Zakat yang akuntabel dan transparan.

Dalam menjalankan tugasnya, Badan Amil Zakat (BAZ) mempunyai landasan yuridis yang dijadikan pedoman dalam pengelolaan dana zakat.

a) Al-Qur'an,

Dalil yang paling jelas tentang tanggung jawab negara dengan petugas dan departemen khususnya adalah firman Allah yang menyebutkan orang-orang yang bertugas mengumpulkan dan menyalurkan zakat, yaitu para petugas zakat, Allah berfirman dalam al-Qur'an surat At-Taubah 103 :

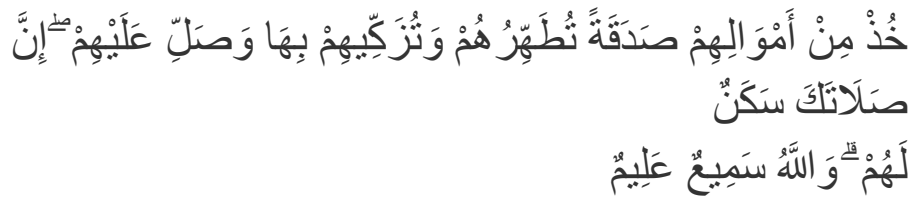

Artinya : "Ambillah zakat dari sebagian harta mereka, dengan zakat itu kamu membersihkan dan mensucikan mereka, dan mendo'alah utuk mereka. Sesungguhnya do'a kamu itu (menjadi) ketentraman jiwa mereka. Dan Allah Maha Mendengar Lagi Maha Mengetahui." (QS. At-Taubah :103). ${ }^{63}$

Dan surat At-Taubah ayat 60:

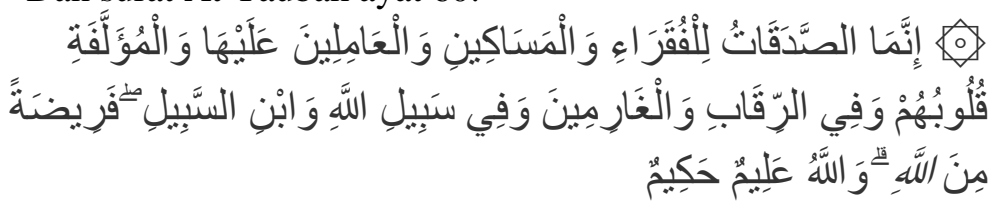

Artinya : "Sesungguhnya zakat-zakat itu, hanyalah untuk orangorang fakir, orang-orang miskin, pengurus-pengurus zakat, para mualaf yang dibujuk hatinya, untuk (memerdekakan) budak,orangorang yang berhutang, untuk jalan Allah dan orang-orang yang sedang dalam perjalanan, sebagai ketetapan yang diwaibkan Allah,

${ }^{63}$ Rozalinda. Fikih Ekonomi Syariah,PT Rajagrafindo Persada, Jakarta, 2017,234 
Jurnal Dinamika Ekonomi Syariah

http://ejurnal.iaipd-nganjuk.ac.id/index.php/es

p-ISSN: 2654-3567

dan Allah Maha Mengetahui Lagi Maha Bijaksana." (QS. At-Taubah :60)

b) Hadist

Ketika Nabi Muhammad SAW mengutus Mu'adz bin Jabal r.a. untuk menjadi qadhi di Yaman, beliau bersabda yang artinya :

"Sesungguhnya engkau, waha muadz akan mendatangani suatu kaumdari golongan yang berkutub. Maka serulah mereka kepada menyaksikan (mengakui) bahwasannya tak ada Tuhan yang sebenarnya disembah melainkan Allah dan bahwasannya aku ini (Muhammad) utusan Allah. Jika mereka telah mentaatimu dalam yang demikian maka, terangkanlah kepada mereka, bahwa: Allah menugaskan atas mereka bersembahyanglima kali dalam sehari semalam, jika yang tersebut ini mereka taati juga, terangkanlah kepada mereka bahwa Allah menugaskan mereka mengeluarkan zakat yang dipungut dari para hartawan mereka lalu diberikan kepada para fakir miskin dari mereka. Jika tugas inipun mereka turuti, maka janganlah engkau mengambil harta-harta mereka yang terbaik saja.Jagalah diri dari do'a orang yang teraniaya, karena tak ada hijab (pendinding) antara do'a orang yang teraniaya."

\section{Manajemen Pengelolaan Zakat}

Manajemen sebagai kata yang diturunkan dari kata to manage mengandung arti mengatur, menata dan mengelola unsur-unsur manajemen. Unsur-unsur manajemen ini diatur dan dikelola dengan tujuan agar roda organisasi berjalan maksimal dan kinerja organisasi dapat tercapai dengan baik dan optimal. Komponen organisasi bisa saling berkoordinasi satu sama lain secara baik dan terintegritas dalam mewujudkan pencapaian tujuan organisasi. Manajemen dipahami sebagai ilmu dan seni mengatur proses pemanfaatan sumber daya manusia dan sumber-sumber lainnya secara efektif dan efisien untuk mencapai tujuan yang telah ditetapkan organisasi.

Manajemen juga diartikan sebagai fungsi untuk mencapai sesuatu melalui orang lain dan mengawasi usaha-usaha individu untuk mencapai tujuan bersama. Dalam pengertian lain menjelaskan bahwa 
proses mendapatkan dan mengkoordinasikan berbagai masukan dalam suatu satuan usaha guna menghasilkan suatu keluaran yang relevan dengan lingkungan sistem juga disebut dengan manajemen. Inti pandangan tersebut menekankan bagaimana sebuah organisasi yang dikendalikan seorang manajer dapat mencapai tujuan yang ditetapkan bersama melalui orang lain. ${ }^{64}$

Manajemen adalah proses perencanaan, pengorganisasian. pengarahan dan pengawasan usaha-usaha para anggota organisasi dan penggunaan sumber daya-sumber daya organisasi lainnya agar mencapai tuiuan organisasi yang telah ditetapkan. Manajemen pengumpulan zakat adalah satu rangkaian aktivitas pengumpulan yang dilaksanakan secara sistematis dengan efisien dan efektif.

\section{Pengelolaan Zakat}

Undang - undang No. 23 tahun 2011 pasal (1) satu ayat (1) satu memaknai pengelolaan zakat sebagai kegiatan perencanaan, pelaksanaan, dan pengorganisasian dalam pengumpulan, pendistribusian dan pendayagunaan zakat ${ }^{65}$. Prinsip - prinsip dari perencanaan adalah :

a. Prinsip membantu tercapainya tujuan setiap perencanaan dan segala perubahannya yang harus ditujukan kepada tercapainya tujuan;

b. Prinsip efisiensi dari perencanaan agar dapat mencapai tujuan dengan biaya yang sekecil-kecilnya;

c. Prinsip pengutamaan, pemerataan, dan patokan dalam perencanaan;

d. Prinsip kebijakan pola kerja;

e. Prinsip waktu yang efektif dan seeffesien mungkin;

f. Prinsip tata hubungan perencanaan;

g. Prinsip alternatif pada setiap rangkaian kerja dan perencanaannya;

h. Prinsip keterikatan dengan memperhitungkan jangka waktu;

${ }^{64}$ Muhammad dan Abu Bakar, Manajemen Organisasi Zakat, Jakarta: Madani, 2011, 43

${ }^{65}$ UU Nomor 23 Tahun 2011 tentang Pengelolaan Zakat 
i. Prinsip ketepatan arah dengan pengamatan yang terus menerus terhadap kejadian-kejadian yang timbul dalam pelaksanaan; dan

j. Prinsip perencanaan strategis dengan memilih tindakantindakan yang diperlukan agar tetap efektif.

Di dalam pengelolaan zakat terdapat perencanaan, pelaksanaan, dan pengorganisasian dalam pengumpulan, pendistribusian dan pendayagunaan zakat. Berikut adalah penjelasan dari hal-hal diatas:

a. Perencanaan

Ruang lingkup kegiatan perencanaan ini dapat dikembangkan dan diperluas pada beberapa langkah sebagai berikut :

b. Perencanaan pengelolaan dana ZIS

Dalam kegiatan ini, ada beberapa hal yang harus diperhatikan, antara lain:

1) Perencanaan strategi kelembagaan.

Perencanaan adalah pemilihan sekumpulan kegiatan dan pemutusan selanjutnya terhadap apa yang harus dilakukan, kapan, bagaimana, dan oleh siapa. Dalam perencanaan ada beberapa aspek yang harus diperhatikan yaitu hasil yang ingin dicapai, apa yang akan dilakukan, kapan waktu dan skala prioritasnya serta berapa jumlah dana yang dibutuhkan.

2) Perencanaan tujuan kelembagaan

Tujuan merupakan suatu harapan yang harus dicapai. Tujuan Pengelolaan zakat adalah :

a) Kemudahan Muzakki menunaikan kewajiban berzakat;

b) Menyalurkan zakat kepada Mustahiq zakat;

c) Memprofesionalkan organisasi zakat; dan

d) Terwujudnya kesejahteraan sosisal.

c. Pelaksanaan pengelolaan dana ZIS 
Yaitu menjalankan layanan sesuai dengan telah direncanakan. ${ }^{66}$ Beberapa hal yang harus dilakukan dalam pelaksanaan pengelolaan dana ZIS antara lain:

1) Pelaksanaan dalam penghimpunan dana ZIS. Pengumpulan zakat dilakukan oleh Amil BAZNAS dengan cara menerima dan atau mengambil dari muzakki atas dasar pemberitahuan terlebih dahulu. BAZNAS dapat bekerjasama dengan Bank dalam pengumpulan zakat harta muzakki yang berada di Bank atas permintaan atau persetujuan muzakki. BAZNAS dapat menerima harta selain zakat, seperti infaq, shadaqah, hibah, wasiat, waris, dan kafarat.

2) Pelaksanaan dalam pendistribusian dan pendayagunaan dana ZIS. Pendistribusian dana zakat sudah dirumuskan dan dikhususkan kepada orang-orang atau golongan yang berhak menerimanya. Agar dana zakat yang didistribusikan tersebut dapat diberdayakan dan dimanfaatkan, maka pembagiannya juga harus selektif untuk kebutuhan konsumtif atau untuk kebutuhan produktif.

d. Pengorganisasian pengelolaan dana ZIS

Pengeorganisasian pengelolaan dana ZIS diperlukan beberapa hal berikut ini, diantaranya adalah :

1) Pengorganisasian struktur organisasi.

Pengorganisasian berkaitan dengan tugas lembaga untuk menyusun struktur, tugas dan wewenang, hubungan, desain organisasi, spesialisasi pekerjaan, uraian pekerjaan, spesifikasi pekerjaan, rentang kendali, kesatuan komando, desain dan analisis pekerjaan.

2) Pengorganisasian mustahik zakat (penerima zakat).

Pengorganisasian para kelompok yang berhak menerima zakat diperlukan agar dana yang terhimpun oleh lembaga BAZNAS dapat didistribusikan, disalurkan dan didayagunakan sesuai dengan syarieeat Islam dan UU yang berlaku. Sehingga

${ }^{66}$ Nurul Huda,Mohamad Heykal,.Lembaga Keuangan Iskam.Jakarta:.Kencana Prenada Media Group,2010,335. 
prosedur tersebut terorganisir dengan mempertimbangkan skala prioritas tiap-tiap mustahik .

3) Pengorganisasian pendayagunaan dana ZIS.

Pendayagunaan dana ZIS dibagi menjadi dua macam, yaitu kebutuhan produktif dan kebutuhan konsumtif. Kubutuhan konsumtif adalah dana zakat yang diperuntukkan untuk pemenuhan kebutuhan hidup para mustahiq yang tergabung dalam delapan ashnaf dengan mendahulukan yang paling tidak berdaya dalam memenuhi kebutuhan primernya dan secara ekonomi mereka juga sangat membutuhkan bantuan. Sedangkan kebutuhan produktif adalah dana zakat yang diperuntukkan untuk kebutuhan usaha produktif bagi para mustahiq yang masih terdapat kelebihan, dan adanya usahausaha yang memungkinkan, serta mendapat persetujuan dari Dewan Pertimbangan

Adapun aktivitas pengumpulan dana ZIS yang dilakukan untuk meningkatkan jumlah muzakki diantaranya adalah :

a. Sosialisasi

Yaitu menjelaskan "ZIS kepada masyarakat yang berpotensi menjadi muzaki sehingga sadar akan kewajibannya dan akan menjalankannya.

b. Promosi

Yaitu menjelaskan tentang kelebihan amil zakat yang akan menerima dan menyalurkan ZIS, sehingga masyarakat tertarik menggunakan jasa amil zakat tersebut.

Adapun strategi pengumpulan dana ZIS terbagi tiga, yaitu:

a. Bellow The Line;

Yaitu aktivitas pengumpulan yang dilakukan secara langsung kepada calon pembayar ZIS di lokasi-lokasi yang di nilai strategisdan potensial, misalnya: membuka stan pameran; dan ' lain-lain. 
b. Above The Line $e^{67}$

Yaitu aktivitas pengumpulan yang dilakukan dengan menggunakan media massa cetak maupun elektronik sebagai alat untuk menarik minat calon pembayar ZIS menggunakan jasa amil zakat tersebut., misalnya: iklan di koran/majalah dan radio/ TV.

c. Aliansi;

Yaitu aktivitas pengumpulan dengan cara melakukan aliansi/ kerja sama dengan lembaga-lembaga lain.

\section{Pengelolaan Zakat di BAZ Kabupaten Nganjuk \\ a) Perencanaan}

Proses awal dalam manajemen zakat, infaq, dan sedekah yaitu perlu adanya perencanaan. Dalam kata-kata hikmah disebutkan "Alinsanu bil-tafkir wallahu bil-taqdir" (manusia yang memikirkan dan Allah lah yang menentukan). Secara konseptual perencanaan adalah proses pemikiran penentuan sasaran dan tujuan yang ingin dicapai, tindakan yang harus dilaksanakan, organisasi yang dicapai, dan orangorang yang bertanggung jawab terhadap kegiatan yang hendak dilaksanakan oleh Lembaga/Badan Amil Zakat. Dengan kata lain perencanaan menyangkut pembuatan keputusan tentang apa yang hendak dilakukan, bagaimana cara melakukan, kapan melakukan, dan siapa yang akan melakukan secara terorganisir. ${ }^{68}$

Terkait dengan perencanaan Zakat tentunya berkaitan dengan kegiatan dengan proses sebagai berikut :

1) Menetapkan sasaran dan tujuan zakat. Sasaran zakat berkaitan dengan orang yang berkewajiban zakat (muzakki) dan orang yang berhak mendapatkan zakat (mustahiq). Sedangkan tujuan adalah menyantuni orang yang berhak agar terpenuhi kebutuhandasarnya atau meringankan beban mereka.

67 Nurul Huda ,Mohamad Heykal.Lembaga Keuangan,... 334.

${ }^{68}$ Ismail Nawawi, Zakat dalam perspektif fiqih,sosial

\&ekonomi, Surabaya, 2010,45-48 
2) Menetapkan bentuk organisasi atau kelembagaan zakat yang sesuai dengan tingkat kebutuhan yang hendak dicapai dalam pengelolaan zakat.

3) Menetapkan cara melakukan penggalian sumber dana distribusi zakat. Dalam hal ini dilakukan identifikasi orang-orang yang berkewajiban zakat (muzakki) dan orang-orang yang berhak menerima zakat (mustahiq). Sehingga teridentifikasi secara tertib dan rapi, sebagai bahan pembuatan program kerja dalam pengelolaan zakat. Penerima zakatpun diperluas pemahamannya, Selain dari pengertian fakir miskin yang telah dirumuskan secara tradisional, dalam pengertian fakir miskin terdapat pula biaya penyantunan orang-orang miskin di lembaga sosial, panti asuhan,dan bantuan modal fakir miskin agar mereka dapat berusaha secara produktif.

4) Menentukan waktu penggalian sumber zakat dan waktu untuk mendistribusikan zakat.

5) Menetapkan amil atau pengelola zakat dengan menentukan orang yang mempunyai komitmen, kompetensi, dan profesionalisme untuk melakukan pengelolaan zakat.

6) Menetapkan sistem pengawasan terhadap pelaksanaan zakat, baik mulai dari pembuatan perencanaan, pembuatan pelaksanaan, pengembangan secara terus menerus secara berkesinambungan.

Perencanaan merupakan fungsi yang paling dasar dari fungsifungsi manajemen lainnya. Perencanaan merupakan proses penentuan Perencanaan ditekankan pada kerangka kerja operasional organisasi zakat untuk mencapai tujuan yang ingin dicapai. Berdasarkan temuan peneliti di lapangan, BAZ Kabupaten Nganjuk menetapkan target yang akan dicapai dalam setahun, yang di tiap tahunnya sama, yaitu peningkatan penghimpunan zakat profesi dan calon muzakki. Sehingga strategi yang digunakan setiap tahunnya sama, yaitu sosialisasi kepada masyarakat, kerja sama dengan instansi pemerintah wilayah kabupaten Nganjuk, dan pembentukan UPZ.

\section{b) Organisasi}

Pengorganisasian sebuah organisasi merujuk pada pembagian tugas dan tanggung jawab masing-masing pihak yang terlibat dalam 
organisasi zakat, infaq, dan sedekah dengan memanfaatkan sarana prasarana yang dimiliki organisasi zakat pengorganisasian, sebaiknya susunan organisasi zakat adalah Badan Amil Zakat (BAZ) yang berfungsi untuk mengumpulkan dan menyalurkan zakat, infaq, dan sedekah ke masyarakat. Organisasi pengelolaan zakat disusun secara networking (terdapat jaringan kerja antara BAZ antar LAZ, dan antar BAZ dengan LAZ). Setiap BAZ/LAZ memiliki wilayah garapan yang jelas dan bekerja pada masing-masing wilayah sesuai dengan tugas dan peran masing-masing. Pengorganisasian kelembagaan organisasi zakat memiliki posisi strategis dalam mengoptimalkan pengumpulan dan pendistribusian zakat. Penataan organisasi diperlukan dalam meningkatkan potensi zakat sebagai instrument pemberdayaan umat. ${ }^{69}$

BAZ Kabupaten Nganjuk menyerahkan tugas penghimpunan zakat profesi kepada Kepala Bagian Pengumpulan dan anggotanya. Sehingga tidak semua bagian melaksanakan tugas penghimpunan zakat profesi. Persiapan sosialisasi, pengajuan iklan dimedia masa dan radio hingga update kegiatan BAZ Kabupaten Nganjuk dalam rangka menarik kepercayaan muzakki menjadi tugas bagian pengumpulan zakat. Selain itu tugas mengajukan kerja sama dengan instansi dengan menggunakan surat perintah hingga surat perintah Bupati juga menjadi tugas bagian pengumpulan zakat.

Manajemen organizing di BAZ Kabupaten Nganjuk yaitu dengan system organisasi sebagai berikut :

1) Dewan Pertimbangan yang betugas memberikan penimbangan tentang pengembangan hukum dan pemahaman zakat kepada badan pelaksana. Serta memberikan bimbingan, pertimbangan, saran dan pendapat dalam kebijaksanaan pengumpulan sem pendayagunaan zakat kepada Badan Pelaksana.

2) Komisi Pengawas yang bertugas melaksanakan pengawasan terhadap tugas administratif kepada Badan Pelaksana dan melaksanakan pengawasan teknis pengumpulan, pendistribusian,

\footnotetext{
${ }^{69}$ Muhammad, Abubakar, Manajemen organisasi Zakat perspektif pemberdayaan umat dan

strategi pengembangan organisasi pengelola zakat,Madani, 2011,60-61
} 
pendayagunaan serta penelitian dan pengembangan pengelolaan zakat.

3) Badan Pelaksana yang bertugas menyelanggarakan tugas administratif Badan Amil Zakat, mengumpulkan dan mengolah data yang diperlukan untuk penyusunan rencana pengolahan zakat., menyelenggarakan tugas pendistribusian dan pendayagunaan zakat serta menyelenggarakan tugas penelitian dan pengembangan, komunikasi, informasi dan edukasi pengelolaan zakat.

Pengurus yang ada di BAZ Kabupaten Nganjuk banyak yang sudah bekerja di instansi lain jadi di BAZ hanya sebagai sampingan saja jadi di harapkan untuk kedepannya perekrutan pengurus BAZ tidak merekrut pekerja ganda.

\section{c) Pelaksanaan}

Pemberian perintah, komunikasi dan koordinasi dalam proses pelaksanaan tugas organisasi yang dilaksanakan BAZ Kabupaten Nganjuk. Ketua BAZ Kabupaten Nganjuk akan memberi perintah kepada Kepala Bagian Pengumpulan zakat untuk mulai melaksanakan tugas bagian pengumpulan zakat. Bagian pengumpulan zakat BAZ Kabupaten Nganjuk akan mulai melaksanakan tugas masing-masing yang telah di bagi oleh kepala bagian pengumpulan zakat termasuk memberi tugas kepada UPZ. Tugasnya adalah melaksanakan semua strategi yang telah ditetapkan sebelumnya dan pengumpulan zakat.

Manajemen pelaksanaan di BAZ Kabupaten Nganjuk dilakukan dengan cara yang sangat sederhana akan tetapi mempunyai dampak yang sangat baik bagi bawahannya, yaitu dengan melalui pelimpahan Wewenang, tugas dan tanggungjawab kepada para bawahannya. Dengan demikian para bawahan dapat dibimbing melalui pelimpahan wewenang sehingga akan tercipta dengan sendirinya rasa tanggung jawab karena adanya limpahan wewenang tersebut. Pimpinan BAZ Kabupaten Nganjuk tidak pernah mengadakan rapat khusus dengan para bawahannya perihal peningkatan kualitas kerja.

d) Pengawasan 
Penekanan pada pengawasan dalam sebuah organisasi terletak pada sistem operasional, pengawasan standart kerja, target-target dan kerangka kerja organisasi. Pengawasan ini adalah pengawasan inti yang dilakukan setiap satu tahun sekali. Dalam pengawasan ini termasuk didalamnya yaitu evaluasi. Pengawasan berkala akan dilaksanakan setiap tiga bulan sekali untuk menghitung jumlah sementara pengumpulan zakat selama tiga bulan.

Kepala Bagian Pengumpulan zakat memberikan laporan akhir pengumpulan zakat profesinya termasuk hambatan-hambatan yang muncul selama melaksanakan pengumpulan zakat profesi. Setelah melakukan laporan, Ketua akan mencocokkan hasil akhir dengan target-target yang di tentukan diawal. Selain itu, ketua juga akan mengevaluasi bagaimana pelaksanaan tugas oleh bagian pengumpulan zakat.

\section{Kendala-Kendala BAZ Kabupaten Nganjuk dalam Meningkatkan Jumlah Muzakki}

Dalam meningkatkan jumlah muzakki dengan upaya yang telah dilakukan seperti iklan di media masa / majalah ,radar Nganjuk, iklan di yellow pages dan disiarkan di radio-radio tetapi masih banyak kendala-kendala yang dihadapi oleh BAZ Kabupaten Nganjuk untuk meningkatkan jumlah muzakki diantaranya kurangnya kesadaran masyarakat dalam berzakat, masih banyak muzakki yang menyalurkan zakat ke masjid-masjid dan ke mustahiq secara langsung, masih banyak orang Islam yang hanya mengetahui kewajiban zakat itu hanya zakat fitrah dan kurangnya kepercayaan terhadap Badan Amil Zakat (BAZ) apakah zakat mereka sudah benar-benar tersalurkan atau belum.

Membangun sistem komunikasi yang permanen yang memungkinkan masyarakat mengetahui secara utuh apa yang dilakukan oleh lembaga zakat, memilih media yang tepat untuk mengkomunikasikan secara efektif dan efisien, seperti bulletin zakat, melakukan komunikasi yang teratur secara tepat seperti komunikasi mingguan dan bulanan,melakukan kerjasama dengan media-media massa, baik local maupun nasional. 
Pada bagian ini, BAZ Kabupaten Nganjuk sudah melakukan kerjasama dengan media periklanan yellow pages untuk mengiklankan layanan BAZ Kabupaten Nganjuk. Sedangkan publikasi kegiatankegiatan BAZ Kabupaten Nganjuk, BAZ Kabupaten Nganjuk bekerjasama dengan Radar Nganjuk yang berada dalam naungan media cetak Jawa Pos. Dengan adanya kegiatan-kegiatan tersebut diharapkan bisa menarik para muzakki untuk menyalurkan zakatnya di BAZ kabupaten Nganjuk.Namun, BAZ Kabupaten Nganjuk masih memiliki kelemahan dalam sosialisasi melalui media karena belum memiliki bulletin zakat sendiri dan belum memiliki portal website walaupun beberapa kali kegiatan BAZ Kabupaten Nganjuk di unggah melalui youtube.com.

\section{Kesimpulan}

Dari pembahasan skripsi ini telah diuraikan mengenai penghimpunan zakat, pendistribusian zakat dan strategi penghimpunan di Badan Amil Zakat (BAZ) Kabupaten Nganjukdapat disimpulkan bahwa manajemen Pengelolaan Zakat di Badan Amil Zakat Nganjuk telah dilaksanakan dengan baik yaitu dengan perencanaan, pengorganisasian, pelaksanaan dan pengawasan. Perencanaan dengan menetapkan sasaran yang ingin dicapai oleh BAZ Kabupaten Nganjuk. Pengorganisasian dengan merekrut pengurus pengurus dari unsur pemerintah, ulama, tokoh masyarakat, cendekiawan, relawan dan ormas Islam. Sedangkan untuk pengawasan, dilakukan dengan mengirimkan laporan keuangan per semester dan dilaporkan tahunan kepada semua UPZ, Kementerian Agama Kabupaten,Bupati Kabupaten Nganjuk dan DPRD Kabupaten Nganjuk.

Pandangan Hukum Islam Terhadap Kebijakan Badan Amil Zakat Kabupaten Nganjuk dalam mengoptimalkan peran dan tugasnya untuk meningkatkan kesadaran masyarakat wajib zakat untuk membayar zakat, BAZ Kabupaten Nganjuk dalam pengumpulan zakat sudah sesuai dengan perintah Allah kepada Rasul (QS.At-Taubah: 103) untuk memungut zakat yaitu, dengan cara BAZ Kabupaten Nganjuk mensosialisasikan secara terus menerus melalui media masa 
(majalah), radio dan media masa lainnya. Kebijakan yang diambil BAZ dalam mensosialisasikan dan memdorong masyarakat agar lebih giat dalam melaksanakan zakatnya sama sekali tidak menentang hukum Islam

Kendala-kendala BAZ Kabupaten Nganjuk dalam meningkatkan jumlah muzakki adalah kurangnya kesadaran masyarakat dalam berzakat, masih banyak muzakki yang menyalurkan zakat ke masjid-masjid dan kemustahiq secara langsung, masih banyak orang islam yang hanya mengetahui kewajiban zakat itu hanya zakat fitrah, kurangnya kepercayaan terhadap Badan Amil Zakat (BAZ) apakah zakat mereka sudah benar-benar tersalurkan atau belum.

\section{Saran}

Sebagai upaya dalam memaksimalkan peran Badan Amil Zakat (BAZ) Kabupaten Nganjuk dalam meningkatkan Jumlah Muzakki adalah :

1. Perlu melakukan sosialisasi zakat kepada masyarakat secara terus-menerus dan berkesinambungan, melalui berbagai forum dan media, seperti khutbah jum'at, majelis ta'lim, seminar, diskusi, melalui media surat kabar, majalah, radio, internet maupun televisi. Dengan sosialisasi yang baik dan optimal, diharapkan masyarakat muzakki akan semakin sadar untuk membayar zakat melalui BadanAmil Zakat yang amanah dan terpercaya.

2. Jemput Bola yaitu petugas BAZ Kabupaten Nganjuk bersedia mengambil zakat ke rumah muazakki, jadi bagi muzakki yang sedang sibuk dan memiliki waktu dapat menghubungi kantor dan petugas akan langsung datang untuk menjemput zakat dari muzakki.

3. Badan Amil Zakat Kabupaten Nganjuk perlu melakukan langkah-langkah strategis yang dapat mengantisipasi terjadinya kendala-kendala dalam meningkat kanjumlah muzakki. 


\section{Daftar Pustaka}

Afifuddin.Metodologi Penelitian Kualitatif, Pustaka Setia, Bandung , 2014

Ahmad IfhamSholihin, Buku Pintar Ekonomi Syariah, GramediaPustaka Utama,Jakarta,2010

Djam'an satori, Aan Komariah, Metodologi Penelitian Kualitatif, Bandung: Alfabeta.2017

Ismail Nawawi, Zakat dalam perspektif fiqih,sosial \&ekonomi, Surabaya, 2010

Izmir Azlan,Hijrah Ahmad,Andhika Prasetya.Panduan ZakatTerlengkap,Tim Emir,Jakarta,2017

Jamal Ma'mur, Tuntunan Lengkap Metodologi Praktis Penelitian Pendidikan

Muhammad dan Abu Bakar, Manajemen Organisasi Zakat, Madani, Jakarta , 2011

Muhammad, Abubakar, Manajemen organisasi Zakat perspektif pemberdayaan umat dan strategi pengembangan organisasi pengelola zakat, Madani, 2011

Nurul Huda, Mohamad Heykal. Lembaga Keuangan Islam,Kencana Prenada Media Group,Jakarta,2010

Rozalinda. Fikih Ekonomi Syariah, PT Rajagrafindo Persada, Jakarta,2017

Sugiyono. Metode Penelitian Kuantitatif Kualitatif Dan $R \& D$, Alfabeta,Bandung, 2014

Surat Edaran Himbauan membayar zakat dan shodaqoh, Bupati Nganjuk

Pasal \& Undang-Undang Nomor 23 Tahun 2011 tentang Pengelolaan zakat 